\title{
Machining of injection mould materials for different cutting flute in low-speed end milling
}

\begin{abstract}
The complexity of mould shapes and the hardness of the mould material contribute to difficulties in machining. Examination of the capability of atypeof cutting tool (Tungsten Carbide Ball Nose) towards machining mould material that is usually used in Injection Moulding Industries. Following this, an experimental work was detailed relating to the use of ball nose end mill to machine hardened injection mould materials (up to $62 \mathrm{HRC}$ ). Surface roughness, surface topography and tool wear data were presented. The relationships of all these three properties respect to each other were also investigated. By machining these materials (Stavax, Stainless Steel, DF3 and XW5), a major wear occur on cutting tool which is called flank wear. Theflank wear is increased by increasing the hardness of the material used. This fact was supported by the result obtained, in which the surface roughness increases when the material hardness increased. Surface topography isdescribed through wavy marks and surface tearing. For 2 and 4-flute cutting tools, the waviness phenomenal ondecreases when material hardness was increased. Meanwhile, for surface tearing, the rate of occurrence is proportional to the increment of the material hardness.
\end{abstract}

Keyword: Ball nose; Mould; Surface roughness; Surface topography; TiALN; Tool life; Tool wear 